\title{
Two Spiny Lobsters of the Genus Panulirus (Crustacea: Decapoda: Palinuridae) from Korean Waters
}

\author{
Jung Nyun Kim*, Jung Hwa Choi, Taeg-Yun Oh, Sung Tae Kim, \\ Hyung Kee Cha and Dae Soo Chang \\ Fisheries Resources Research Division, National Fisheries Research and \\ Development Institute, Busan 619-705, Korea
}

\begin{abstract}
Two spiny lobsters of the genus Panulirus, $P$. stimpsoni Holthuis, 1963 from Jeju Island and $P$. versicolor (Latreille, 1804) from Busan, are briefly described with colorations. These lobsters are new members of the Korean decapod crustacean fauna. Morphological and distributional accounts of these species are discussed.
\end{abstract}

Key words: Panulirus stimpsoni, Panulirus versicolor, Palinuridae, Decapoda, Korea, New record

\section{Introduction}

The spiny lobster genus Panulirus contains 19 species worldwide (Holthuis, 1991). To date, only two species, Panulirus japonicus (Von Siebold, 1824) and $P$. penicillatus (Olivier, 1791), have been reported from Korea, both from southern coastal waters (Kim and Kim, 1997). During the course of a taxonomic study of Korean decapod crustaceans, members of two additional species of Panulirus were collected: P. stimpsoni Holthuis, 1963 from the southern coast of Jeju Island and $P$. versicolor (Latreille, 1804) from the southern coast of Busan. Here we describe these two spiny lobsters, and for comparative reasons, briefly describe and discuss the other species of Panulirus known to be distributed in Korea.

Examined specimens are deposited in the Fisheries Resource Research Division, National Fisheries Research and Development Institute (NFRDI). Postorbital carapace length (CL) was used as the standard length of the specimens. Terminology mainly follows Holthuis (1991) and Chan and Yu (1993).

\section{Systematic Accounts}

Panulirus stimpsoni Holthuis, 1963

(New Korean name: Ma-dak-saewoo)

(Fig. 1A)

\footnotetext{
*Corresponding author: crangonk@nfrdi.go.kr
}

Panulirus ornatus: Stimpson, 1860: 24 (not Palinurus ornatus Fabricius, 1798).

Panulirus stimpsoni Holthuis, 1963: 54; George and Holthuis, 1965: 6, 7 ; Burukovsky, 1974: 101; Holthuis, 1978: 96, pl. 1; 1991: 155, fig. 291; Chan and $\mathrm{Yu}, 1993: 145,2$ unnumbered figs.

Panulirus japonicus: Cha et al., 2001: 164, 1 unnumbered fig. [not Panulirus japonicus (Von Siebold, 1824)].

\section{Type locality}

Hong Kong.

\section{Material examined}

From Jungmun, southern coast of Jeju Island, 15$25 \mathrm{~m}$, gill net, October 27, 2002, 1 male (CL 82.1 $\mathrm{mm})$, NFRDI.

\section{Diagnosis}

Carapace subcylindrical with branchiostegal areas slightly inflated, pubescent and having many welldeveloped spines; anterior margin with 4 regularly spaced large spines other than supraorbital horns. Supraorbital horns slightly less than or about two eyes high with spinules in-between. Abdominal tergites II to VI having broad sunken pubescent areas on each half, and with those at tergites II and III very conspicuous. Abdominal pleura with anterior margins smooth but posterobasal margins serrated in pleura II to V. Eyes large and kidney-shaped. Antennular plate armed with two pairs of well separated principal spines (anterior pair noticeably larger than posterior) as well as many spines and spinules. Antennular 


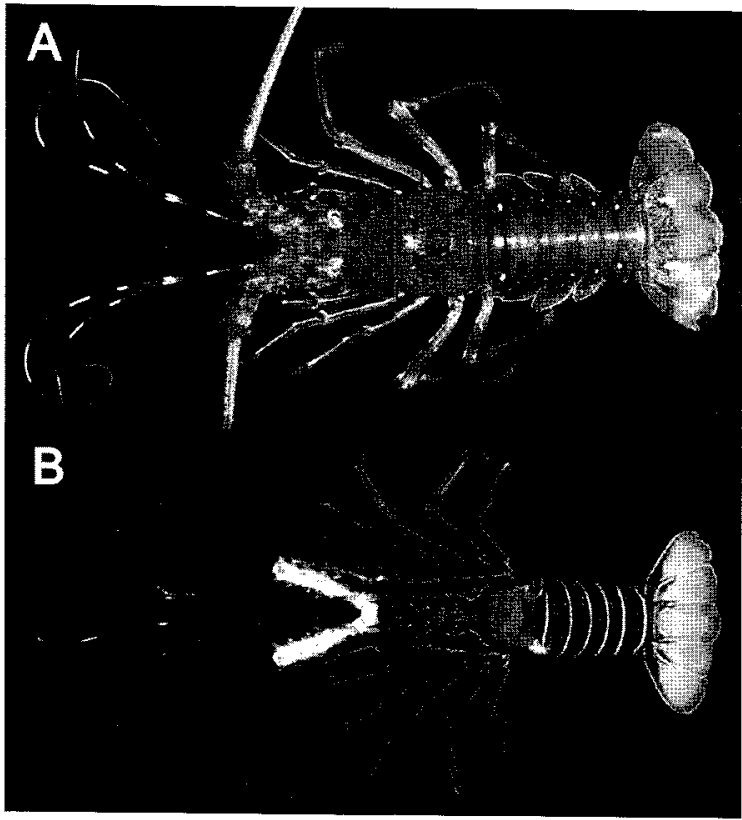

Fig. 1. A, Panulirus stimpsoni Holthuis, 1963, female (CL $82.1 \mathrm{~mm}$ ) from southern coastal waters of Jeju Island; B, Panulirus versicolor (Latreille, 1804), juvenile (CL $20.2 \mathrm{~mm}$ ) from southern coastal waters of Busan.

flagella roughly as long as body length. Third maxilliped lacks exopod.

\section{Coloration}

Body generally greenish dark brown. Carapace without peculiar marbling near base of frontal horns. Supraorbital horns banded with brownish yellow markings. Eyes brown. Abdomen with sunken areas somewhat brownish; normal eyespot in anterior half above base of each pleura. Antennular flagella alternated with brown and yellowish white bands. Perepods striped with yellowish white lines. Pleopods reddish brown.

\section{Distribution}

Indo-West Pacific region: coast of southern China between Shanghai and Shantou, Taiwan, Hong Kong, Gulf of Thailand; at less than $40 \mathrm{~m}$ in reef areas (Chan and Yu, 1993). Off southern coast of Jeju Island at $15-25 \mathrm{~m}$ in this study.

\section{Size}

Maximum male CL $130 \mathrm{~mm}$, commonly 65-105 $\mathrm{mm}$ (Chan and $\mathrm{Yu}, 1993)$.

\section{Remarks}

Panulirus stimpsoni is easily distinguished from the two previously known Korean Panulirus, $P$. japonicus (Von Siebold, 1824) and $P$. penicillatus (Olivier, 1791) due to its smooth abdominal somites without transverse grooves and its third maxilliped lacking an exopod. The color photograph of "Panulirus japonicus" by Cha et al. (2001: 164), which shows the entire animal in dorsal view, matches well with the present species in having abdominal somites with a large pubescent area on each half of the dorsal surface (Fig. 1A). Therefore, little doubt exists that the photograph by Cha et al. (2001) was of $P$. stimpsoni, and not $P$. japonicus, although the descriptions were based on $P$. japonicus. This species occurs in the coastal waters of southern China, Taiwan and the Gulf of Thailand, and extends its ranges northward to Korean waters.

Panulirus versicolor (Latreille, 1804)

(New Korean name: Huin-jul-dak-saewoo)

(Fig. 1B)

Palinurus versicolor Latreille, 1804: 394.

Palinurus taeniatus Lamarck, 1818: 211.

Panulirus versicolor: Holthuis, 1991: 156, fig. 293;

Chan and Yu, 1993: 151, 2 unnumbered figs.; Miyake, 1998: 83, pl. 28, fig. 2; Chan, 1998: 1021, 1 unnumbered fig.

\section{Type locality}

Mauritius, eastern Africa

\section{Material examined}

From Namuseom Island, southern coast of Busan, $7 \mathrm{~m}$, SCUBA diving, November 8, 2001, 1 juvenile (CL $20.2 \mathrm{~mm}$ ), NFRDI.

\section{Diagnosis}

Carapace subcylindrical with surface almost naked and having many strong spines; anterior margin with 4 large and regularly spaced spines other than supraorbital horns. Supraorbital horns more than three eyes high and without spinules in between. Abdomen more or less smooth with only broad but shallow sunken pubescent areas at each half of tergites II and III, more distinct at tergite II. Abdominal pleura with anterior margins smooth but posterobasal margins serrated in pleura II to V. Eyes large and kidney-shaped. Antennular plate armed with two pairs of well separated principal spines only, anterior pair larger than posterior. Antennular flagella almost as long as body length. Third maxilliped lacks exopod.

\section{Coloration}

In juvenile, body generally dark blue and brown. Carapace brownish in central region; whitish spots 
and longitudinal lines on both lateral sides. Eye black brown. Abdomen dark brownish blue, with white line along posterior margin of each somite. Antennular peduncle inner whitish pink. Perepods blue and distinctly striped with white lines. Pleopods dark blue. Non-calcified part of tail-fan brownish blue.

\section{Distribution}

Indo-West Pacific region: entire Red Sea and east coast of Africa (south to Natal), to southern Japan, Micronesia, Melanesia, northern Australia and Polynesia; at less than $16 \mathrm{~m}$ (mostly $4-12 \mathrm{~m}$ ) in reef areas, nocturnal and not gregarious, in daytime, hides in crevices and cavities of the rocks (Holthuis, 1991; Chan and Yu, 1993). Off southern coast of Busan at 7 $\mathrm{m}$ in this study.

\section{Size}

Maximum CL $150 \mathrm{~mm}$, commonly $75-112.5 \mathrm{~mm}$ (Chan and $\mathrm{Yu}, 1993$ )

\section{Remarks}

Panulirus versicolor is similar to $P$. stimpsoni in having smooth abdominal somites without transverse grooves and the third maxilliped lacking an exopod. However, it is easily distinguishable from $P$. stimpsoni by having first to sixth abdominal somites with a distinct uninterrupted white transverse band along the posterior margin (Fig. 1B). Although the present species is widely found in the Indo-West Pacific region, it has never previously been recorded from Korean waters. The present record extends the northern range of this species from southern Japan to the southern coast of Busan.

\section{Acknowledgements}

This work was funded by the National Fisheries Research and Development Institute (RP-2009-FR047).

\section{References}

Burukovsky RN. 1974. Opredeliteli krevetok, langustov i omarov. Pishchevaya Promyshlennost' Publishers, Moscow, 1-128. [Translated in 1985 by Sharma BR. In: Kothekar VS, ed. Russian translation series 5, A.A. Balkema, Rotterdam, 1-174.]
Cha HK, Lee JU, Park CS, Baik CI, Hong SY, Park JH, Lee DW, Choi YM, Hwang K, Kim ZG, Choi KH, Sohn H, Sohn MH, Kim DH, and Choi JH. 2001. Shrimps of the Korean Waters. NFRDI, Busan, 1-188.

Chan TY. 1998. Shrimps and prawns. In: FAO species identification guide for fishery purposes. The living marine resources of the Western Central Pacific. Vol. 2. Cephalopods, crustaceans, holothurians and sharks, Carpenter KE and Niem VH, eds. FAO, Rome, 851971.

Chan TY and Yu HP. 1993. The Illustrated Lobsters of Taiwan. SMC Publishing Inc., Taipei, 1-247.

George RW and Holthuis LB. 1965. A revision of the IndoWest Pacific spiny lobsters of the Pamulirus japonicus group. Zool Verhand Leiden 72, 1-36, pls. 1-5.

Holthuis LB. 1963. Preliminary descriptions of some new species of Palinuridea (Crustacea, Decapoda, Macrura Reptantia). Proc Kon Nederl Akad Wetensch (C) 66, 54-60.

Holthuis LB. 1978. Notes on Panulirus stimpsoni Holthuis, 1963 (Decapoda, Palinuridae). Crustaceana 34, 95100 , pl. 1.

Holthuis LB. 1991. FAO species catalogue. Volume 13. Marine lobsters of the world. An annotated and illustrated catalogue of species of interest to fisheries known to date. FAO Fisheries Synopsis (125) 13, 1 292.

Kim HS and Kim W. 1997. Order Decapoda. In: List of Animals in Korea (Excluding Insects), Kor Soc Syst Zool, 212-223.

Lamarck JBPA de. 1818. Histoire naturelle des animaux sans vertèbres $5,1-612$.

Latreille PA. 1804. Des langoustes du Museum National d'Histoire Naturelle. Ann Mus Hist Nat 3, 388-395.

Miyake S. 1998. Japanese crustacean decapods and stomatopods in color. Volume I. Macrura, Anomura and Stomatopoda. Hoikusha, Oksaka, 3rd printing, 1-261.

Stimpson W. 1860. Prodromus descriptionis animalium evertebratorum, quae in Expeditione ad Oceanum Pacificum Septentrionalem, a Republica Federata missa, C. Ringgold et J. Rodgers Ducibus, observavit et descripsit. Proc Acad Nat Sci Philadelphia 12, 2247.

(Received 8 October 2009; Revised 3 November 2009; Accepted 5 December 2009) 